\title{
The Spirit and salvation?
}

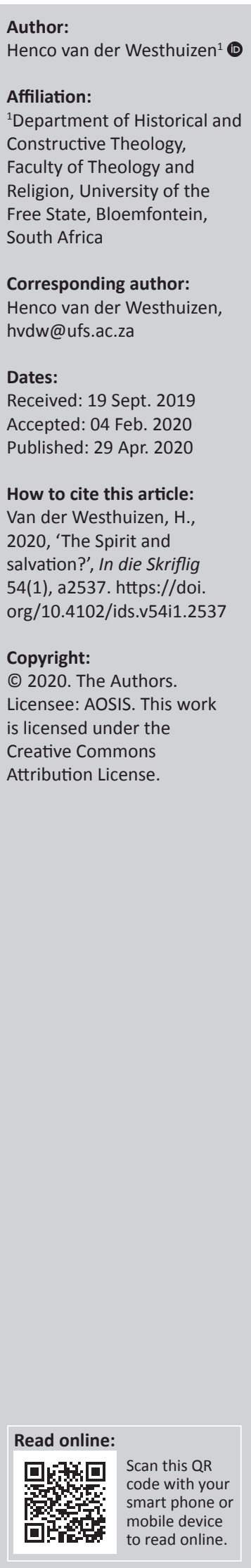

To answer the question of the relation between the Spirit and salvation, this article explores Michael Welker's theology of the Trinity. I argue that Welker's Trinitarian theology, with its focus on the activity of the triune God, is built on his theology of the Spirit. The Spirit, I argue, allows him to understand the salvific activity of the triune God realistically. The first three parts of the article will focus on Welker's Trinitarian understanding of salvation, by looking at the sacraments, particularly at holy communion as a mirror of the salvific activity of the triune God. The fourth and final part will analyse Welker's theology of the triune God in light of Dirk J. Smit's analysis of the Trinity, thereby shedding light on Welker's understanding of the activity of the triune God, on the one hand, and on the relation between the Spirit and salvation, on the other.

Keywords: Trinity; doctrine of God; pneumatology; Christology; salvation; sacraments.

\section{Introduction}

There are many ways to ask about the relation between the Trinity and salvation in the theology of Welker.

In the second half of his more recent Gottes Offenbarung (2012a), translated as God the revealed (Welker 2013a), Welker, for example, discusses in detail what he refers to as the threefold form of the reign of God. In the first part of the last chapter, he discusses the richness and breadth of salvation in relation to this reign. He reiterates that the reign of God 'reveals the loving, preserving, salvific, and uplifting activity of the triune God' (Welker 2012a:211). Although the reign is discussed in his theology of Jesus Christ, ${ }^{1}$ which is closely related to his theology of the Spirit, he has made it clear that salvation can only be understood by means of a theology of the Trinity.

Welker (2009a; 2010a; 2010b; 2011) has published several essays on the Trinity. For him the Trinity, or the doctrine of the triune God, is 'der Schlüssel zu einem Verständnis Gottes' (Welker 2014a). Interesting to this key to an understanding of God is an essay entitled, 'Which forms and themes should Christian theology uphold in dialogue with secular culture?', published in a Festschrift for Daniel L. Migliore (Welker 2009b). In this essay, he deals with what he refers to as top topics in theology. ${ }^{2}$ The Trinity, or at least an understanding thereof - and this is what is interesting - is not included as a top topic.

The reason for it not being included, is clear in the important essay entitled, 'God's eternity, God's temporality, and Trinitarian theology' (Welker 1998), where he, as part of a multiyear project at the Centre for Theological Inquiry at Princeton, asks how a bottom-up rather than a top-down approach is fruitful in the area of Trinitarian theology. His argument is that top-down Trinitarian theology has too often been restricted to 'very meagre or completely vague, basic ideas of God' on the one hand, and by the mere 'introduction of anthropological phenomena or figures of thought into the doctrine of God', on the other (Welker 1998:319). He therefore wants to understand the Trinity as is also clear regarding the reign from the perspective of God's activity. ${ }^{3}$

Welker wants to look at the theology of the Trinity through the lens of a theology of the Spirit. In fact, in a footnote in Gottes Geist (Welker 1992a), translated as God the Spirit (Welker 1994), he describes his theology of the Spirit as initial steps in the direction of a Trinitarian theology.

1.Compare Welker (2013a:209-216; also 1992b; 2002a; 2014c) as well as Welker and Wolter 2009c.

2.These top topics are the doctrine of creation (Welker 2009b:303); the relationship between the imago Dei and the divine call to human dominion (Welker 2009b:304); the doctrine of $\sin$ (Welker 2009b:304); the cross and resurrection of Christ (Welker 2009b:305); the body of Christ (Welker 2009b:307); Christ's parousia (Welker 2009b:307); the doctrine of the Holy Spirit (Welker 2009b:309) as well as body of Christ (Welker 2009b:307); Christ's
the law and the Spirit (Welker 2009b:310).

3.In terms of the question in the title of this article, Welker wants to understand God's activity in relation to a plurality of temporalities. He understands eternity from the perspective of the plurality of temporalities. 
To understand the saving work of the Trinity by means of a theology of the Spirit, this essay focuses on Welker's theology of the Trinity through yet another lens, that is the lens of his theology of the sacraments, which is integrally linked to the Spirit. For him the sacraments are indeed impressive mirrors that allows for a refined appreciation of the Spirit. This, in turn, allows for a renewed apprehension of a Trinitarian richness in the sacraments, that is, of God's triune activity (Welker 2003a).

In 'Baptism as change of Lordship', he links baptism directly to a theology of the Trinity: 'the creative, sustaining, saving, and ennobling God establishes a relation to us through baptism, by guiding us through death into life' (Welker 2005a:111). This is also the case when he discusses baptism in Gottes Offenbarung (Welker 2012a):

Baptism in the name of the triune God attests such a radical turn in human life, for it is through baptism that human beings allow themselves to be filled with God's saving power that creates new life from death. (p. 287)

When examining the priestly form of the reign of God and baptism in relation to this form, he emphasises that 'correctly understood and correctly celebrated worship serves to disclose, secure, and deepen our knowledge of God, knowledge of God that is always also knowledge of salvation' (Welker 2013a:279).

The relation between holy communion and salvation is particularly clear in What happens in Holy communion? (Welker 2000), translated from Was geht vor beim Abendmahl? (Welker 1999a). He concludes the book with a chapter on 'God, the Father and the Son and the Holy Spirit'. ${ }^{4}$ As an answer to the question in the title, he accentuates that, in holy communion, 'human beings enter into a relationship with the triune God'. In fact, they meet (Welker 2000):

[T] he living God, the Creator who created them and preserves their life, who is revealed in Jesus Christ as liberator from the power of sin, and who as Holy Spirit raises human beings up and enables them to be bearers of God's faithful, liberating and life-giving presence. (p. 167)

The first three parts of this article will focus on Welker's Trinitarian understanding of salvation, particularly as he relates salvation to the Spirit by looking at the sacraments, particularly at holy communion. The fourth and final part will analyse Welker's theology of the Trinity in light of Dirk J. Smit's analysis of the Trinity in the Reformed tradition, thereby shedding light on Welker's Reformed understanding of the activity of the triune God, inter alia, on the Spirit and salvation.

\section{God? - 'Gott als Schöpfer und Erhalter der Welt'}

In the first chapter of What happens in Holy communion?, 'Do this ... who is supposed to do what?' (Welker 2000:29-42),

4.It is interesting that the book is divided into three parts, which, in a way, relate to the Trinity, that is, to God the 'Father' (Part 1), the 'Son' (Part 2) and the Holy Spirit (in a way, Part 3) respectively.
Welker answers the question by arguing that a community that is gathered, celebrates a symbolic community meal. The celebration of the symbolic community meal is not to be separated from the gathered community. This celebration is more than a meal, he argues, and this more should not lead to less. Where these insights are fading away, the meal is to be celebrated with a full community meal, at least infrequently.

It is not only that the symbolic community meal is not to be separated from the gathered community. The gathered community's symbolic actions should not be separated from the meal.

The stress on the Eucharist, on celebratory thanksgiving, should not side-line the set of actions that characterise the meal. This is the case, as the specific actions related to the thanksgiving are lost. There are many ways of thanking the triune God. In holy communion, however, God is thanked in a very specific way that is linked to the symbolic set of actions characterising the meal, that is the actions related inter alia to the distributing, taking as well as eating and drinking of the bread and wine respectively.

Welker's point is that the relation between God and human beings, and the relation among human beings themselves should not be separated. Thanks are given not only for the bread and the wine, but also for the bread and the wine that is given. For Welker, to give thanks to God is directly linked to what is given to one another.

What happens in this symbolic community meal, is reciprocal welcome and acceptance among human beings (Welker 2000:55-68), inter alia, through what is given. In this meal, all are responsible for welcoming and accepting, which are symbolically disclosed by the fact that all are given bread and wine. Welker (2000) highlights that there is no better way of symbolising basic relations among human beings:

At no other place ... does it become clear in such a way that all human beings are equal before God and that all human beings are bound together before God in the most intense way. (p. 139)

It is therefore important for him to focus clearly on the described 'articulated and ritual process' (Welker 2000:59):

By not regarding the complex symbolic action that is carried out in the table community's celebration of the meal, we run the danger of hatching and sending out into the world all sorts of chimerical conceptions and magical notions. (p. 60)

Welker adds that, as important as it is to focus on these symbolic aspects of the meal, it is imperative that these relations should not be reduced to relations among human beings. The meal can in fact, be misused by being reduced merely to such relations (Welker 2000:62). The relations between human beings among one another, and the relations of God and human beings, he reiterates, should not be separated.

He highlights the fact that thanks are given not merely for the giving of the bread and the wine. Thanks are given to the 
God who allows for the activity that brings forth bread and wine. Welker's theology of creation, where that which has been brought forth brings forth, that is where that which is brought forth, takes part in the creating activity of God, is important here. ${ }^{5}$ For bread and wine to be bread and to be wine asks not only for natural relations. They are not merely gifts of nature. For Welker, these are gifts of creation.

For bread and wine to be what they are, thus asks for both natural and social relations that are reciprocally beneficial to each other (Welker 2000:64). In fact, flourishing vegetation has just natural and social relations as preconditions, that is reciprocal relations characterised by the biblical law of justice and mercy. ${ }^{6}$ Thus, to thank God not merely for the bread and the wine, but also for the activity that brings forth bread and wine, is to thank God for relations of justice and mercy. For Welker (2000:65), thanking God is indissolubly connected with this law.

It is important in light of this reference to biblical law, to ask about the meaning of 'whoever, therefore, eats the bread or drinks the wine of the Lord in an unworthy manner' (Welker 2000:69-83).

For him, eating the bread and drinking the wine in an unworthy manner is related to the identity of the meal. This identity lies therein that holy communion is about the unconditional acceptance of all who take part in it. To ask about the 'unworthy manner' in which the meal is taken part in, is to ask where the meal does not disclose this: that God unconditionally accepts all who take part therein, unconditionally.

The meal is not merely for those we wish to include. Welker constantly reiterates that, in this meal those who participate go out of their way to include also those we do not wish to include. This becomes particularly clear in Welker's (2000:43-54) reference to 'the night in which he was betrayed'. The acceptance 'reaches an exemplary apex', in the meal, he argues as it is a meal for those excluded.

This is important for an understanding of the saving action of God (Welker 2000:116). A theology of nature alone does not allow for an adequate response to the question of salvation, because humanity, as Welker highlights, always lives at the cost of others.

The essay entitled, 'Der erhaltende, rettende und erhebende Gott', published in Der lebendige Gott: Auf den Spuren neueren trinitarischen Denkens (Welker 2005b) and later in Der lebendige Gott als Trinität (Volf 2006), the latter a Festschrift for Jürgen Moltmann, is of particular importance in this regard.

Welker (2006) refers to the ambivalence of a theology confined to a mere natural theology of creation, that is a theology limited to the bringing forth of all nature:

5.Compare Welker (1988; 1991; 1995a; 1995b; 1997; 1999b; 2001; 2005c).

6.Compare Van der Westhuizen (2019).
Ich werde im Folgenden zunächst auf die tiefe Ambivalenz und letzte Trostlosigkeit einer Wahrnehmung von Schöpfer und Schöpfung aufmerksam machen, die sich nur auf die Hervorbringung, Erhaltung und Bewahrung der natürlichen Welt konzentriert [In the following, I will first of all draw attention to the profound ambivalence and ultimate lack of comfort of a perception of creator and creation, which concentrates only on the production, preservation and protection of the natural world]. (p. 36 [author's own translation])

In line with Calvin's thought on natural theology, ${ }^{7}$ Welker refers here to the inability to discern God's activity merely in nature. It does not allow for adequate discernment of God's activity (Welker 2006):

Calvin weist schonungslos darauf hin: Auf dieser Basis können die Menschen niemals zwischen ihren Phantasien und Einbildungen und der wahren Erfahrung Gottes unterscheiden ... Mit vernichtender Nüchternheit stellt Calvin solche frommen Illusionen bloß ... Das Empfinden der Gottheit durch natürliches Ahnvermögen, dem menschlichen Geist eigen, bleibt vage oder - wie Calvin sagt - ein 'eitles und flüchtiges' Wissen [Calvin points out relentlessly: on this basis, people can never distinguish between their fantasies and conceits and the true experience of God ... With devastating sobriety, Calvin exposes such pious illusions ... The sense of divinity through a natural instinct inherent in the human mind, remains vague, or as Calvin says, a 'vain and fleeting' knowledge]. (p. 40 [author's own translation])

It is therefore important to also look at the saving action of God (Welker 2010b):

We reach an even deeper basis to the doctrine of the Trinity when we connect insights into its Christological foundation with a clear understanding of the biblical creation narratives ... Thus the ... work of God, which has called creation into life, also needs God's ... salvific action in order to demonstrate the fullness of God's creativity. (p. 92)

The question, however, is: How does theology move towards the action not only of the Father, but also of the Son, thus towards a Trinitarian theological appropriation of God? Is God not precisely then not discernible in the resurrected and crucified Jesus Christ? (Welker 2006):

Doch wie kommen wir von den schöpfungstheologischen Überlegungen von den Beobachtungen zu den dunklen Seiten der Schöpfung, zu den Grenzen des abstrakten Omnipotenzdenkens und zu den Ambivalenzen der natürlichen Religiosität, wie kommen wir von dort aus zu einem trinitätstheologischen Erkenntniszugang zu Gott? Betreten wir mit der Konzentration auf den Menschen Jesus Christus und auf der Gekreuzigten nicht einfach eine andere Welt, völlig andere Erfahrungsbereiche? Ist die Forderung, im Menschen Jesus und in Kreuz und Leiden Gott zu erkennen, nicht eine unerträgliche Zumutung? Warum wird Gott in der Inkarnation und in Kreuz und Leiden nicht gerade völlig unkenntlich? [But how do we get from a theology of creation's thinking about the dark sides of creation, to the limits of abstract thinking of omnipotence and the ambivalence of natural religiosity? How do we get from there to a Trinitarian theology of God? Do we not, by focusing on the human and crucified Jesus Christ, just enter another world, absolute different areas of experience? Is the demand to recognize God in the human Jesus and in the cross and suffering not completely

7.Compare Welker (1999b:21-32; 2006:38-41). 
incomprehensible? Why does God not become altogether unrecognisable in the incarnation and in the cross and suffering?]. (p. 36 [author's own translation])

Welker thus turns to the saving work of God in Jesus Christ (Welker 2006):

Zweitens wird zu bedenken sein, was es heißt, dass Gott sich erhaltend und rettend, schöpferisch und neuschöpferisch der Welt im gekreuzigten, auferstandenen und erhöhten Christus und durch ihn zu erkennen gibt [Secondly, it is worth considering what it means that God, who preserves and saves, who creates and creates anew, reveals himself to the world in and through the crucified, risen and exalted Christ]. (p. 36 [author's own translation])

\section{God the Revealed? - 'Die Selbstoffenbarung des rettenden Gottes'}

Welker's theology of holy communion also allows for an apprehension of the saving work of God in Jesus Christ. ${ }^{8}$ The question here is: How is Jesus Christ really present in the meal? What is meant by 'This is my body ... this is my blood'? (2000:87-100).

Welker's first answer to the question is that, in holy communion the risen Jesus Christ is realistically, that is really present. With him 'the reconciliation of human beings with God is present, and the reconciliation of humans among themselves becomes effective' (Welker 2000:87).

This is clarified by the reference to body and blood. For Welker, blood is the power of life. Life power is in the blood, and the body is the bearer of that power of life. Life here and now is possible because of body and blood. In addition to bearing life, the body and blood allow human beings to be perceivable. Although it is not the only aspect that allows for this, body and blood do perpetuate human beings' perceivable vitality, and the life power in the blood that this body embodies. This is what Jesus identifies himself with. By identifying his body and blood with the bread and the wine, he gives human beings that in and through which he lives.

The relation between the body and the blood given in the crucifixion, and the bread and the wine that are given and taken, becomes clear in the fact that the bread and wine are gifts of creation as described above. In the meal, Christ not only gives these gifts of creation. He is this gift. In this manner, the resurrected Christ is really present inasmuch as human beings, focused on Christ that gives himself, celebrate reconciliation with God and with each other.

Important for Welker is that the resurrected Christ is really bodily present. Yes, this Christ embodies the entire life of who Jesus is. In short, the question of how this Christ is really bodily present in this manner, is answered by the identification of the bread and the wine with the body and the blood. In fact, the reality of the twofold reconciliation with God and 8.Compare Van der Westhuizen (2015) and Welker (2012a; 2013a). with each other, takes together the being of Jesus Christ (Welker 2000:96).

The importance of this reconciliation is reiterated in Welker's recurring focus (2000:101-115) not only on the night of betrayal, but also the phrase: 'As often as you eat the bread and drink the wine, you proclaim Christ's death.' In fact, as is clear from the above, the crucifixion of Jesus Christ is at the centre of the meal.

This is to be proclaimed as often as the meal is celebrated. It is proclaimed, he argues, as the power of sin is rendered present here. The crucifixion of Christ places before us 'the unsurpassable depths of the human power for destruction and self-destruction' (Welker 2000:106). It places before them "'human beings" abysmal power to spread destruction' (Welker 2000:106). The point for Welker is that, in this situation of sin, we are dependent on the saving action of God. For this reason, it is to be proclaimed 'until he comes' (Welker 2000:116-125).

What is proclaimed, is a situation that Christ 'has anticipated' (Welker 2000:110). In his presence, human beings have 'salvation in its entirety' (Welker 2000:119). This is, however, anticipated. He therefore argues that the coming of Jesus Christ is not to be confined to $a$ community, to a time and place. Focused on Christ who gives himself for reconciliation, he is really bodily present - also beyond the present. On the one hand, this Christ is not without his own and, on the other hand, he is not limited to a community. In other words, the community relates to a reality of Christ that is entirely present in and beyond the community (Welker 2000:96).

For Welker, the point is that we are not to absolutise our world. In fact, human beings are to move beyond any absolutising conceptions that simply take this world further (Welker 2000:118). This is important, as Jesus Christ is 'given for you', but also 'shed for many' (Welker 2000:137-148):

Concentrating solely on the concretely gathered community and its experiences of certainty can degenerate into group ideology, niche ideology, and deceptive self-certainty. The ideological selfdeception is dangerous precisely because all the 'neighbours' who are directly present are ready to support and strengthen it. (p. 140)

Welker refers to the dynamic relation between his being 'present' and his anticipated 'coming', the 'for you' and 'for many', which allows him to take seriously the liveliness of Christ in this time and place and beyond.

He relates the liveliness of Jesus Christ to the work of the Holy Spirit, and asks if it is possible to react to the question of salvation with reference to Jesus Christ alone (Welker 2006):

Ist das Leben und Wirken Jesu Christi nicht zu klein, um überzeugend das schöpferische und neuschöpferische Wirken Gottes prägend zum Ausdruck zu bringen? Erst auf diesem Niveau des Fragens erreichen wir die Ebene der zu entfaltenden Trinitätstheologie [Is the life and work of Jesus Christ not too small to 
convincingly express the creation and new-creational work of God? Only at this level of questioning do we reach the level of unfolding Trinitarian theology]. (p. 47 [author's own translation])

He therefore turns to the activity of the Holy Spirit (Welker 2006):

Wir müssen (drittens) versuchen, die Kraft des Heiligen Geistes in der Schöpfung und die die Schöpfung erhebende Teilgabe am göttlichen Leben zu erfassen [Thirdly, we must try to understand the power of the Holy Spirit in creation and the gift of divine life which uplifts creation]. (p. 36 [author's own translation])

\section{God the Spirit? - 'Die Erhaltung, Rettung und Erhebung der Schöpfung'}

The theology of the Spirit is the basis on which Welker builds his theology. ${ }^{9}$ For him, interestingly, holy communion is an impressive mirror that allows for a more differentiated appreciation of the activity of God, the Spirit (Welker 2003c:154).

In his theology of the Spirit, the activity is often related to memory. In What happens in Holy Communion?, he, for example, relates what the Spirit is up to the phrase: 'Do this in remembrance of me' (Welker 2000:126-133). ${ }^{10}$ The memory of Christ is brought forth by the Holy Spirit. Christ is, in fact, present in the Spirit, which, for him, means, inter alia, in recollections (Welker 2000:16).

He deliberately describes this recollection as living memory that is more than mere recollections of the past. In light of a distinction between 'communicative' and 'cultural' memory, between 'hot' and 'cold' memory, Welker refers to 'living cultural memory' or 'living canonical memory', to differentiate what he means with this remembrance of Christ.

Through this powerful memory, brought forth through the Spirit and in relation to the biblical traditions, Christ is rendered present from a multitude of perspectives. ${ }^{11}$ This rendering present of Jesus Christ in a multitude of perspectives, 'owes itself to the activity of God's Spirit, the Holy Spirit' (Welker 2000:132).

For Welker, on the one hand, the Holy Spirit who is the Spirit of Jesus Christ, renders him present. On the other hand, it is through the Spirit that Christ is present in the here and now through his own. Welker (2000:130) mentions a multitude of events set in motion.

In God the Spirit, this saving work of the Spirit is described most realistically. Already in the first chapter, where he deals with the as yet unclear experiences of the Spirit (Welker 1994:1-49), he relates the Spirit to salvation:

\section{Van der Westhuizen (2016a); Welker (1992a; 1994).}

10. He refers, inter alia, to Luke 22:19 and 1 Corinthians $11: 24$ and 25 .

11.In the introduction to What happens in Holy communion?, Welker (2000:16) mentions that instead of this particular memory, he could also say 'faith'.
Even the early experiences of the Spirit are experiences of how a new beginning is made toward restoring the community of God's people. They are experiences of the forgiveness of sins, of the raising up of the 'crushed and oppressed', and of the renewal of the forces of life. Certainly these early experiences are unclear and in many respects questionable. Yet even they can lead one to think of the third article of the Creed, which talks about the communion of saints, about the forgiveness of sins, about the resurrection of the dead and the life everlasting. (p. 65)

In the last chapter of the same book, he conjoins the insights from his biblical-realistic perspective on the Spirit and incorporates them into his own conception of the mentioned third article.

He (Welker 2000:303-315) begins with the communion of the sanctified, that is, with a description of the many ways in which the world is not only endangered, but also endangering itself. His point is that it is in this world, endangered and endangering itself, that the Spirit of God is a reality.

The Spirit is not an 'ideal, a product of wishful thinking, a dream of a different future or a general moral alternative to be uncovered or conjured up' (Welker 1994:307). The Spirit is a reality amid this world. And human beings in the Spirit, whether they know or do not know this, belong to a reality that works against the spirit of the Western world, the spirit of self over and against others. This self over and against others is, in fact relativised by the Spirit of God.

What the Spirit does, is not only clearly recognisable in churches. The Spirit is also recognised clearly in the world in which the churches find themselves. The Spirit in this world forms a community, that is, a communion with the crucified and risen Jesus Christ. Through this community, God inscribes Godself in the world through the Spirit (Welker 1994:309).

This community witnesses in constantly new ways not to itself, but to this Christ in a multitude of perspectives. It is to this human being that the communion of the sanctified becomes a witness as a domain of resonance. It is in the concentration on this Christ that this communion as domain of resonance takes on definite contours. He refers to this communion of resonance as the public person of the Spirit. The Spirit, to reiterate, is the public person of Christ.

In this way, the community participates in the power of the Resurrected. The power in which this community participates, however, is also the power of the Crucified, that is, of Selbstlosigkeit or selflessness, and Selbstzurücknahme or selfwithdrawal, and freier, schöpferischer Selbstzurücknahme zugunsten von Mitmenschen, that is free, creative, selfwithdrawal on behalf of others ${ }^{12}$ (Welker 1994):

The persons who arrive in the communion of the Holy Spirit and who are filled with the Spirit of Christ not only perceive the revealed mystery of sacrifice and free self-withdrawal. They become witnesses of the 'life-giving Spirit'; they become members of Christ's body; they stand in intimate communion 12.Compare Welker (2012a:208-218; 2013a:223-234) 
with Christ; through word and deed they pass on Christ's message, the expression of Christ's will. The people who participate in this power of free-self-withdrawal and of sacrifice for the benefit of others in order likewise to help others to know their lostness, their deliverance, and their vocation as witnesses to this power of the Crucified One - these people are addressed as those who are 'called to holiness'. (p. 310)

Here Welker also refers to the difference between the person of the Spirit and the person of Christ. It is in light of the crucifixion of the resurrected Christ that, for Welker, he has no resonance. Here, the Spirit of God is distinguished from the spirits of the world. This is the case, as it is precisely for the world that conspires against this God in Jesus Christ, that the Spirit of this God is given.

Welker (1994:315-325) refers to this as 'the forgiveness of sins and life reborn on the basis of God's righteousness'. He describes forgiveness of sins as the only possibility to halt sin and its resonance. ${ }^{13}$ What the Spirit does in forgiveness, is thus not to be limited to the possibilities human beings have within themselves. Rather the Spirit potentiates, what Welker refers to as 'neue Lebenszusammenhänge', that is new patterns of life (Welker 1992a:292). They are not only brought into these patterns of life, but also participate within these life patterns. For Welker (1994:318), however, this participation is and remains participation through the Spirit:

It is a process that accrues to them, that comes upon them, and into which they are drawn. The people who are part of the Spirit's action of forgiving sins and who are affected by this action are not only bearers, but also are borne. They are not only mediators, but also receivers. They not only exercise an influence on their surroundings, but also are affected, strengthened, challenged, and changed by the actions and reactions of others. In this ... being surrounded and borne up, the persons who are renewed by the action of the Spirit and are borne up by the process are indeed themselves changed. They themselves are a part of this process, and they themselves collaborate in it. (p. 319)

Welker refers to this, being brought into and being participants within new patterns of life brought about by the Spirit, as rebirth. He links this rebirth, that is and remains rebirth through the Spirit on the one hand, to the pouring out, and to the Spirit being the Spirit of Jesus Christ, on the other hand. The Spirit being poured out simultaneously, brings about rebirth in patterns of life, not limited to $a$ time and place. In these times and places, the rebirth through the Spirit potentiates the fulfilling of the intentions of the law, that is of the reign of God.

Welker, however, does not limit the forgiveness of sins, brought about through the Spirit, to the abstract beyond and above patterns of life. Whatever God has brought forth in and through creation, is brought about through the Spirit. In light of Welker's theology of creation, it is clear that for him,

13.Welker's chapter (2000:149-160) on the question as to whether holy communion emphasises the power of sin or eternal life, is important here. Although for him, the meal is also about eternal life; he does not want the meal's emphasis on sin merely to be taken into what it says about eternal life. forgiveness of sin and the salvation brought forth by it, are not about whatever is above and beyond (Welker 1994:325).

Rather through the forgiveness of sins, human beings are brought into the reality of the communion of the living and the dead. What he means by this reality, is described in a chapter on 'exaltation and illumination in the communion of the living and the dead' (Welker 1994:325-331).

For Welker, the life brought about by the Spirit, is life that is free from clinging to itself. This life is free to withdraw itself, to not live at the cost of others. By withdrawing itself and not living at their cost, it benefits other lives. This benefitting of others is not limited to one's own living or dying.

Here Welker refers to the resurrection of the flesh. The resurrection of the flesh, like the forgiveness of sins, allows him to understand the continuity of life that has been brought into patterns of life. For him, fleshly life resurrected is life that has been brought to life by the Spirit through the discontinuity of death. In the resurrection of the flesh, fleshly life in the Spirit is not limited to living or dying to a time and place. It is life eternal (Welker 2010b):

The salvific work of God - revealed in Jesus Christ and in the power of the Holy Spirit - is not merely a series of attempted repairs or 'touch-ups' on what still remains (despite its powers and impotence, its strengths and frailties) a 'life-supporting' creation. While never ceasing to support this creation in its freedom, the Triune God works toward the transformation and elevation of all creatures into 'members of the new creation'. God seeks to gain all creatures for the divine kingdom. They should be formed after the image of Christ, filled with the power of the Holy Spirit, and receive a share in the eternal life of God. (p. 93)

For Welker, eternal life is not life after life in the flesh. It is life that, in its fleshliness through the Spirit, has been exalted and illuminated. For Welker, to be exalted and illuminated by the Spirit, is to through the Spirit be the place in time where the glory of God is made present eternally (Welker 1994:330).

The presence of the glory of God through this exaltation and illumination by the Spirit in and beyond times and places, is not limited. This eternal life is therefore not a life, for example remembered, and thus eternal. This life is not limited by the capacity of fleshly human beings to remember.

The Spirit through this exaltation and illumination, brings about intimacy with God. In fact, for Welker (1994:331), the Spirit is this intimacy that brings human beings into the presence of the glory of God eternally. It is in this presence that human beings, precisely as human beings through the Spirit, participate in this eternal glory (Welker 1994:331-341).

For Welker, to participate in this glory is to participate in free self-withdrawal, or free, creative, self-withdrawal on behalf of others. In this free self-withdrawal, in this joy of free selfwithdrawal, Welker finds the salvific work of the triune God today. 
It is this line of thought that he more recently took in " Rooted and established in love": The Holy Spirit and salvation', when dealing directly with the question of the Spirit and salvation. Is it really possible, he asks, to relate the mentioned self-withdrawal to salvation?

Welker argues that it is possible to conceptualise the depth of salvation when it is clarified how self-withdrawal turns on its head the tendency of what he refers to as natural life, that is, life that lives at the cost of other lives. It is, he argues, through free and creative self-withdrawal for the benefit of others that human beings here and now, are exalted and illuminated to experience the full powers of salvation. In fact, 'to be filled with the fullness of God already here and now - this is exactly the experience of salvation' (Welker 2015:193).

\section{Preliminary conclusion}

How does Welker's understanding of the Trinity relate to South African Trinitarian theologies, particularly theologians in the Reformed tradition? This preliminary conclusion will analyse Welker's theology of the Trinity in light of Dirk J. Smit's analysis of the Trinity in the Reformed tradition, thereby shedding light on Welker's understanding of the activity of the triune God one the one hand, and on the relation between the Spirit and salvation on the other. ${ }^{14}$

In 'The Trinity in the Reformed tradition', Smit (2009a) asks if it is possible to distinguish a Reformed perspective on the Trinity. For him, this is a difficult question to answer, as the Reformed tradition did not uncritically appropriate the tradition of Trinitarian theology. Rather, the Reformed tradition critically appropriated this tradition in plurality. There is not $a$ Reformed perspective on the Trinity, but a plurality of perspectives. Thus, it is always a question whether perspectives on the Trinity are to be broadened to include more perspectives, or whether a perspective is to be excluded as not being Reformed (Smit 2009a:58). This plurality of perspectives on the Trinity is also discernible with regards to the Trinity in South Africa. ${ }^{15}$

Despite the described difficulties in answering the question of the Trinity in the Reformed tradition, Smit argues for at least five motifs that do appear regularly in the Reformed tradition, representing at least $a$ Reformed perspective on the Trinity, allowing for an understanding of the activity of the triune God, that is on the Spirit and salvation. ${ }^{16}$

As a first motif of a Reformed perspective on the Trinity, Smit mentions that the theology of the Trinity provides a biblical grammar, that is a way to 'think Old and New Testament together', to think of the 'one God of both Testaments'

14. Welker has through the years taken part in several projects having to do with the Reformed tradition: Toward the future of Reformed theology: Tasks, topics, traditions (Welker \& Willis 1998); Reformed theology: Identity and ecumenicity
(Welker \& Alston 2003) and Reformed theology: Identity and ecumenicity II: Biblical interpretation in the Reformed tradition (Welker, M. \& Alston 2007). Compare also Welker (2003b).

15.Compare, in this regard, for example Vosloo (1999; 2002; 2004); Venter (2012; 2016; 2018)

16.Compare Smit (2001a; 2001b; 2001c; 2003; 2006; 2008a; 2008b; 2009b; 2012).
(Smit 2009a:59-61). For him, this perspective is not about quoting biblical traditions as proofs, but rather about 'discerning a pattern' within the Bible.

Clearly Welker (2006:34-52) is also concerned with this biblical grammar in his essay, 'Der erhaltende, rettende und erhebende Gott: $\mathrm{Zu}$ einer "biblisch" orientierten Trinitätslehre'. ${ }^{17}$ The title of the publication already refers to the second motif. The biblical grammar moves them 'to a different kind of Trinitarian language', that is a language attentive to 'the actions of the living God' (Smit 2009a:62-66). Due to their concern with the God of the biblical traditions, they deliberately are not that concerned with the immanent Trinity, but with the economic.

Although Welker (2010b:92) in 'Faith in the Triune God', published in the International Journal of Orthodox Theology, has, for example, acknowledged the importance of the immanent Trinity, he is also concerned with the economic Trinity:

This differentiated divine action which sustains, saves and elevates creation takes into account the doctrine of the Trinity, within the scope of teaching on the economic Trinity. Although the Father, Son and Holy Spirit are at work together in all the creative, redemptive and salvific works of the Triune God, the differing dimensions of this work and their vital interconnections can only be understood clearly when approached from the perspective of a Trinitarian differentiation. (p. 93)

This is, for example also the case in Gottes Geist (1992a) where Welker deliberately discusses the Trinity only where the topic of Trinitarian theology comes up from below.

For Smit, this concern with the activity of the living God leads to a third motif - that of a Trinitarian spread (Smit 2009a:66-69). For him, a Trinitarian account of the activity of the living God 'always seems to help to speak in more differentiated ways about the rich and complex, dynamic and surprising ways of the biblical account' (Smit 2009a:67). This is also the case for Welker whose point is that a Trinitarian account allows for a differentiated account, inter alia, of salvation, also today.

Smit's fourth motif has to do with a pastoral purpose. He explains what he means by referring to Welker's essay (2006) 'Der erhaltende, rettende und erhebende Gott'. Welker (2006) accentuates that a theology of the Trinity is not a theological Glasperlenspiel, that is a glass bead game that does not take seriously reality, inter alia, of meaningless and senseless destruction:

Nicht das Interesse an einem theologischen Glasperlenspiel ist dabei leitend. Die Trinitätslehre soll vielmehr helfen, den langen Atem des Glaubens zu verstehen und zu bewahren inmitten der Erfahrungen zerstörerischer Sinnlosigkeit und 'Zweckwidrigkeit' in dieser Welt [It is not the interest in a theological glass bead game that is guiding here. Rather, the doctrine of the Trinity is meant to help one understand and sustain the long breath of faith, amidst the experiences of destructive meaninglessness and senseless lack of purpose in this world]. (p. 36 [author's own translation])

17.For a perspective on Welker's biblical realistic theology, Compare Van der Westhuizen (2016b; 2017; cf. also especially Welker 2002b). 
For him, the Trinity has a pastoral purpose, to reiterate the words of Smit, that allows for an ability to persevere amidst the mentioned realities of meaningless and senseless destruction.

In an essay on 'The Heidelberg Catechism and its potential for the future', Welker (2014c), inter alia links salvation to a single word, Trost, that is, comfort. ${ }^{18}$ The catechism of course, begins with the question: 'What is your only comfort in life and in death?' (Question 1). For Welker (2014c), the word Trost, in this light:

[...] stands for security; it stands for hope; it stands for trust and self-confidence; courage in the face of danger and also in the face of life. It is associated with lasting dependability, help, stability, advice, salvation, with calmness and tranquillity, with strength, support, shielding and protection, but also with sympathy, compassion and encouragement. (p. 285 [author's own emphasis])

As a fifth motif of a Reformed perspective on the Trinity, Smit mentions that the theology of the Trinity provides a practical pattern. For him, this practical pattern is not about the practical consequences that can be deduced from the Trinity. Rather, it is that (Smit 2009a):

[T] he biblical language about the one living God who is for us, with us and in us will have practical consequences for who we are and what we are called to be. (p. 75)

This is Welker's argument (2000:161-166) in a chapter on 'God's peace be with you! - Go in peace', as well as in the chapter 'In the Name of God, the Father and the Son and the Holy Spirit' (Welker 2000:167-176) in What happens in Holy Communion? ${ }^{19}$ The God who is for us, with us and in us, has practical consequences for who we are and what we are called to be - this is what happens in holy communion.

In light of the above, it is clear that Welker's approach to the theology of the Trinity is Reformed in its particular emphasis on the activity of the Trinity. His understanding of this activity - that has to do with salvation - is built on his theology of the Spirit. This allows him to understand the saving activity of the triune God realistically.

\section{Acknowledgement Competing interest}

The author declares that no competing interest exists.

\section{Author(s) contributions}

I declare that I am the sole author of this research article.

\section{Ethical consideration}

This article followed all ethical standards for carrying out research.

\section{Compare also Welker (2012b)}

19.Compare also Welker (2013b).

\section{Funding information}

This research received no specific grant from any funding agency in the public, commercial, or not-for-profit sectors.

\section{Data availability statement}

Data sharing is not applicable to this article as no new data were created or analysed in this study.

\section{Disclaimer}

The views and opinions expressed in this article are those of the author and do not necessarily reflect the official policy or position of any affiliated agency of the authors.

\section{References}

Smit, D.J., 2001a, Vernuwe! - na die beeld van ons Skepper: Wat Christene bely oor God die Skepper, Lux Verbi.BM, Wellington.

Smit, D.J., 2001b, Lig uit lig: Wat Christene bely oor Jesus Christus, Lux Verbi.BM, Wellington.

Smit, D.J., 2001c, Wat Here is en lewend maak: Wat Christene bely oor die Heilige Gees, Lux Verbi.BM, Wellington.

Smit, D.J., 2003, 'Prediking oor Christelike roeping', in C.W. Burger, B.A. Müller \& D.J. Smit (eds.), Woord teen die Lig III/6, Riglyne vir die prediking oor roeping, pp. 8-26, Lux Verbi.BM, Wellington.

Smit, D.J., 2006, 'Church unity in freedom?', in M. Volf \& M. Welker (eds.), God's life in Trinity, pp. 73-92, Fortress Press, Minneapolis, MN.

Smit, D.J., 2008a, 'Oor die God wat ons roep', in N. Koopman (ed.), Geloof en openbare lewe: Versameling opstelle 2, pp. 159-166, Sun Press, Stellenbosch.

Smit, D.J., 2008b, 'Oor die hoop wat in ons leef', in N. Koopman (ed.), Geloof en openbare lewe: Versameling opstelle 2, pp. 167-174, Sun Press, Stellenbosch.

Smit, D.J., 2009a, 'The Trinity in the Reformed Tradition', Journal of Reformed Theology 3(1), 57-76. https://doi.org/10.1163/156973109X403723

Smit, D.J., 2009b, 'Quo Vadis, Sistematiese Teologie?', Scriptura 100(1), 42-53. https://doi.org/10.7833/100-0-651

Smit, D.J., 2012, 'Trinity, history - and discernment?', Nederduitse Gereformeerde Teologiese Tydskrif 54(3/4), 336-352. https://doi.org/10.17570/stj.2015.v1n2.a34

Van der Westhuizen, H., 2015, "'God the revealed: Christology" Michael Welker's response to Dietrich Bonhoeffer's question', Stellenbosch Theological Journal 1(2) 711-730. https://doi.org/10.17570/stj.2015.v1n2.a34

Van der Westhuizen, H., 2016a, “"God the Spirit" - Michael Welker's "biblical-realistic theology"', Stellenbosch Theological Journal 2(1), 463-490. https://doi.org/ 10.17570/stj.2016.v2n1.a23

Van der Westhuizen, H., 2016b, 'The Word and the Spirit - Michael Welker's theological hermeneutics, Part 1', Stellenbosch Theological Journal 2(2), 607-620. https://doi.org/10.17570/stj.2016.v2n2.a27

Van der Westhuizen, H. 2017, 'The Word and the Spirit - Michael Welker's theological hermeneutics, Part 2', Stellenbosch Theological Journal 1(1), 429-449. https://doi. org/10.17570/stj.2017.v3n1.a20

Van der Westhuizen, H. 2019, 'The Spirit and the law', Verbum et Ecclesia 40(1), 429-449. https://doi.org/10.4102/ve.v40i1.1933

Venter, R., 2012, 'Thinking about God today: Eavesdropping on some discourses', NGTT 53(Suppl 3), 195-204. https://doi.org/10.5952/53-0-233

Venter, R., 2016, 'The Triune God in South African Systematic Theology since 1976', in R. Venter (ed.), Theology and the (post)apartheid condition: Genealogies and future directions, pp. 156-168, Sun Press, Bloemfontein.

Venter, R., 2018, 'God in Systematic Theology after Barth: Trends and perspectives', Stellenbosch Theological Journal 4(2), 303-333. https://doi.org/10.17570/ stj.2018.v4n2.a15

Volf, M. \& Welker, M. (eds.), 2006, Der lebendige Gott als Trinität: Jürgen Moltmann zum 80. Geburtstag, Gütersloher Verlagshaus, Gütersloh.

Vosloo, R., 1999, 'Being created in the image of the Triune God: The Trinity and human personhood', Theological Forum 27(1/2), 13-33.

Vosloo, R., 2002, 'The gift of participation: On the Triune God and the Christian mora life', Scriptura 79(1), 93-103. https://doi.org/10.7833/79-0-775

Vosloo, R., 2004, 'Identity, otherness and the Triune God: Theological groundwork for a Christian ethic of hospitality', Journal of Theology for Southern Africa 119, 69-89.

Welker, M., 1988, 'Schöpfung', in V. Drehsen \& M. Baumotte (eds.), Wörterbuch des Christentums, pp. 1119-1120, G. Mohn, Gütersloh.

Welker, M., 1991, 'Was ist 'Schöpfung'? - Genesis 1 und 2 neu gelesen', Evangelische Theologie 51(1-6), 208-224. https://doi.org/10.14315/evth-1991-1-623 
Welker, M., 1992a, Gottes Geist: Theologie des Heiligen Geistes, Neukirckener Verlag, Neukirchener-Vluyn.

Welker, M., 1992b, 'The "reign" of God', Theology Today 49, 500-515. https://doi. org/10.1177/004057369304900406

Welker, M., 1994, God the Spirit, Fortress Press, Minneapolis, MN.

Welker, M., 1995a, Schöpfung und Wirklichkeit, Neukirchener Verlag, Neukirchen-Vluyn.

Welker, M., 1995b, 'Creation: Big bang or the work of seven days?', Theology Today 52, 173-187. https://doi.org/10.1177/004057369505200202

Welker, M., 1997, 'Creation and the image of God: Their understanding in Christian tradition and the biblical grounds', Journal of Ecumenical Studies 34(3), 436-448.

Welker, M., 1998, 'God's eternity, God's temporality, and Trinitarian theology', Theology Today 55(3), 317-328.

Welker, M., 1999a, Was geht vor beim Abendmahl? Gütersloher Verlagshaus, Gütersloh.

Welker, M., 1999b, Creation and reality, Fortress Press, Minneapolis, MN.

Welker, M., 2000, What happens in Holy Communion?, Eerdmans, Grand Rapids, MI.

Welker, M., 2001, 'Schöpfung in den kanonischen biblischen Überlieferungen und in der Programmatik eines Lehrplans', in H. Schmidt \& H. Rupp (eds.), Lebensorientierung oder Verharmlosung? Theologische Kritik der Lehrplanentwicklung im Religionsunterricht, pp. 22-32, Calwer, Stuttgart.

Welker, M., 2002a, 'Theological realism and eschatological symbol systems: Resurrection, the reign of God, and the presence in faith and in the Spirit', in T. Peters, R. Russell \& M. Welker (eds.), Resurrection: Theological and scientific assessments, pp. 31-42, Eerdmans, Grand Rapids, MI.

Welker, M., 2002b, 'Sola scriptura? The authority of Scripture in pluralistic environments', in B. Strawn (ed.), A God so near, FS Patrick D. Miller, pp. 375-391, Eisenbrowns, Winona Lake, MN.

Welker, M., 2003a, 'Holy Spirit and Holy Communion', Word and World 23(2), 154-159.

Welker, M., 2003b, 'Reformation theology and the reformed profile', The Bulletin of the Institute for Reformed Theology 3(1), 1, 4-9, 16.

Welker, M., 2005a, 'Baptism as change of lordship', in B. Gaventa \& P.D. Miller (eds.) The ending of Mark and the ends of God, FS Donald Harrisville Juel, pp. 107-114, Westminster \& John Knox, Louisville, KY.

Welker, M., 2005b, 'Der erhaltende, rettende und erhebende Gott: Zu einer biblisch orientierten Trinitätslehre', in R. Weth (ed.), Der lebendige Gott: Auf den Spuren orientierten Trinitätslehre', in R. Weth (ed.), Der lebendige Gott: Auf den Sp
neueren trinitarischen Denkens, pp. 3-128, Neukirchener, Neukirchen-Vluyn.

Welker, M., 2005c, 'Gott ist keine Zaubermacht: Über die Todesflut, falsche Allmachtsvorstellungen und eine unzerstörbare Hoffnung', Zeitzeichen 6, 48.

Welker, M., 2006, 'Der erhaltende, rettende und erhebende Gott: Zu einer biblisch orientierten Trinitätslehre', in M. Volf \& M. Welker (eds.), Der lebendige Gott als Trinität: Jürgen Moltmann zum 80. Geburtstag, pp. 34-52, Gütersloher Verlagshaus, Gütersloh.
Welker, M., 2009a, 'Offene Fragen aushalten: Was die Menschen gerade auf dem Gebiet der Religion brauchen, ist Ehrlichkeit', Zeitzeichen 10(12), 30-32.

Welker, M., 2009b, 'Which forms and themes should Christian theology uphold in dialogue with secular culture?', in B.L. McCormack \& K.J. Bender (eds.), Theology as conversation: The significance of dialogue in historical and contemporary theology, FS Daniel L. Migliore, pp. 297-312, Eerdmans, Grand Rapids, MI.

Welker, M., 2010a, 'Relation: Human and divine', in J. Polkinghorne (ed.), The Trinity and an entangled world: Relationality in physical science and theology, pp. 157-167, Eerdmans, Grand Rapids, MI.

Welker, M., 2010b, 'Faith in the Triune God', International Journal of Orthodox Theology 1(1), 94-97.

Welker, M., 2011, 'Artikel: Trinität', in H. Rupp \& M. Mühling (eds.), Gott, Schülerheft, Oberstufe Religion, pp. 232-234, Calwer, Stuttgart.

Welker, M., 2012a, Gottes Offenbarung: Christologie, Neukirchener, Neukirchen-Vluyn.

Welker, M., 2012b, "'Herrschaft" Christi als "Trost"', in M. Heimbucher, C. SchneiderHarpprecht \& A. Siller (eds.), Zugänge zum Heidelberger Katechismus: GeschichteThemen - Unterricht, pp. 166-170, Neukirchener, Neukirchen-Vluyn.

Welker, M., 2013a, God the revealed: Christology, Eerdmans, Grand Rapids, MI.

Welker, M., 2013b, 'Role model - God's image: Life-giving Spirit: Who is Jesus Christ for us today?', in D.J. Downs \& M.L. Skinner (eds.), The unrelenting God: God's action in Scripture, FS Beverly Roberts Gaventa, pp. 277-289, Eerdmans, Grand Rapids, MI.

Welker, M., 2014a, 'Geheimnisvolle Trinität: Die Lehre vom dreieinigen Gott ist der Schlüssel zu einem Verständnis Gottes', Evangelische Zeitung für die Kirche in Norddeutschland, 15 Juni, p. 7.

Welker, M., 2014b, 'Gott der Vater nach dem Heidelberger Katechismus', in A. Huijgen, J.V. Fresko \& A. Siller (eds.), Handbuch Heidelberger Katechismus, pp. 203-207, Gütersloher, Gütersloh.

Welker, M., 2014c, 'What profit is the reign of Christ to us? The Heidelberg Catechism and its potential for the future', Acta Theologica (suppl 20), 280-292. https://doi. org/10.4314/actat.v20i1.18S

Welker, M., 2015, '“Rooted and established in love": The Holy Spirit and salvation', in J.W. Barbeau \& B. Felker Jones (eds.), Spirit of God: Christian renewal in the community of faith, pp. 183-193, InterVarsity, Downers Grove, IL.

Welker, M. \& Alston, W.M., 2003, Reformed theology: Identity and ecumenicity, Eerdmans, Grand Rapids, MI.

Welker, M. \& Alston, W.M. Jr., 2007, Reformed theology: Identity and ecumenicity II: Biblical interpretation in the reformed tradition, Eerdmans, Grand Rapids, MI.

Welker, M. \& Willis, D., 1998, Toward the future of Reformed theology: Tasks, topics, traditions, Eerdmans, Grand Rapids, MI.

Welker, M. \& Wolter, M., 2009, 'Unscheinbarkeit des Reiches Gottes', Marburger Jahrbuch Theologie XI, 103-116. 